\title{
Until I Could Be Sure: How I Stopped the Death Penalty in Illinois
}

\author{
By George H. Ryan Sr with Maurice Possley \\ (New York, Rowman \& Littlefield, 2020) \\ Reviewed by James R. Acker \\ Distinguished Teaching Professor Emeritus, University at Albany \\ Albany, New York
}

George H Ryan Sr served as Governor of the State of Illinois from 1999 to 2003. A Republican who held multiple elected offices over a political career that began in the late 1960s, Ryan voted to reinstate Illinois' death penalty in 1977 as a member of the state House of Representatives after the previous capital-sentencing law was declared unconstitutional. He supported the death penalty during his gubernatorial campaign and following his election he allowed the execution of Andrew Kokoraleis to go forward in 1999. Kokoraleis' execution would be the last one carried out in Illinois. Lawmakers repealed the state's death-penalty legislation in 2011. Ryan's decision as Governor to impose a moratorium on future executions in January 2000, and his subsequent action before leaving office in January 2003 to issue a blanket commutation to 167 inhabitants of the state's death row and pardon four others, were of singular importance in fortifying and stimulating anti-capital punishment movements within the United States. Until I Could Be Sure, written with Maurice Possley, formerly a reporter with the Chicago Tribune and now a researcher for the National Registry of Exonerations, chronicles Ryan's evolving thinking about the death penalty and explains how and why he reached his epic decisions to halt executions and ultimately to clear Illinois' death row. No issue weighed more heavily on Ryan than the everlooming threat that the death penalty would claim the life of an innocent person.

Ryan had good reason to be concerned that innocents were at risk of wrongful execution. When he announced his moratorium decision in early 2000, 13 death-sentenced individuals had been exonerated in Illinois following the death penalty's reinstatement in 1977, while 12 executions had taken place. "I have grave concerns about our state's shameful record of convicting innocent people and putting them on death row," Ryan declared. "Until I can be sure that everyone sentenced to death in Illinois is truly guilty, until I can be sure with moral certainty that no innocent man or woman is facing a lethal injection, no one will meet that fate" (p 68).

Ryan's resolve to suspend executions and later to clear the state's death row was hardened by Anthony Porter's exoneration, which by Ryan's admission "caused something inside me to shift" (p 21). Porter's case was particularly instrumental because it prompted Ryan to "put a human face on the issue of wrongfully convicted death row inmates" ( $p$ 26). Porter had been sentenced to death in 1983 following his conviction for a double murder in Chicago. He came within two days of dying by lethal injection when his lawyer convinced the Illinois Supreme Court to issue a stay to have Porter, whose IQ reportedly was 51, undergo a mental competency exam. The reprieve enabled journalism students working under the supervision of Northwestern University Professor David Protess to investigate Porter's claim of innocence. A private investigator working with them secured a confession from another man, Alstory Simon, that he committed the killings for which 
Porter was sentenced to death. Porter was exonerated in March 1999, just two months after Ryan assumed office. "How does this happen in America?" Ryan wondered:

What is going on that journalism students - not the courts, not a jury, not a prosecutorgot to the bottom of this? What is wrong with a system that allows somebody to get sentenced to death and spend sixteen years on death row and then someone finds out that they are innocent? (p 20).

Spurred by Porter's case and other developments, including the powerful November 1998 Northwestern University Law School conference which brought to a single stage 31 death row exonerees from across the country, and investigative reporting by the Chicago Tribune that exposed problems plaguing scores of the state's capital cases, in March 2000 Ryan appointed a 14-member Death Penalty Moratorium Commission to study Illinois' capital-punishment system. He asked the Commission to make recommendations "designed to further ensure the application and administration of the death penalty in Illinois is just, fair, and accurate" ( $p$ 77). The Commission issued its report following two years of study, setting forth 85 recommendations pursuant to its charge. Ryan gleaned two key conclusions from the report: that the Commission believed that "the death penalty system in Illinois was broken and they couldn't find a way to make absolutely certain that everyone sentenced to death actually was guilty beyond any doubt" (p 150). Ryan chafed as the Illinois legislature not only failed to act on the Commission's recommendations but even passed a bill expanding the reach of the state's death-penalty law, which Ryan vetoed. Deeming these developments unacceptable, his commitment grew to take matters into his own hands.

As time passed, Ryan became a sought-after participant and speaker in death-penalty forums across the country. He maintained for some time at these events that he remained uncertain about the fate of those awaiting execution in Illinois, and in particular whether his ongoing review of individual cases would be sufficient to ensure that no innocents were put to death, or whether he would instead have to act more broadly and commute the sentences of all then on the state's death row. Ryan had announced that he would be a one-term governor, meaning that he would leave office in January 2003. Mindful that his tenure was drawing to a close, a team of lawyers organized a campaign to file clemency petitions on behalf of all of the 171 individuals on Illinois' death row with the state Prisoner Review Board by the end of August 2002. The Board was responsible for making non-binding recommendations to the Governor about whether clemency should be granted. The glut of filings led the Board to conduct abbreviated hearings-denounced by a Cook County state attorney as a "Reader's Digest form of justice" ( $p$ 170) - in mid-October. The hearings dramatically highlighted the pain endured by murder victims' family members as many of them recounted the horrific deaths their loved ones had suffered. Their moving testimonies were portrayed sympathetically in media outlets and Ryan perceived that public sentiment had decisively shifted away from the plight of those on death row. He announced that: "I've pretty much ruled out blanket commutation based on the hearings and the information I've gathered so far" (p 187).

Ryan later scheduled two private meetings with victims' family members, one in Chicago and one in Springfield. He acknowledged stating during those meetings that "a blanket commutation was not a likely occurrence" ( $p$ 193). He also met with family members of the 
condemned, who shared their own emotionally powerful stories with him. A former high school classmate whose mentally ill son was sentenced to death for murdering a police officer asked a nonplussed Ryan point-blank, "Are you going to kill my son?" (p 200). Racked with conflicting sentiments, Ryan's thoughts continued to return to his conviction that Illinois' death-penalty system was broken and could not be trusted to guard against the awful prospect of causing an innocent person to be executed.

Ryan ultimately reached his decision to pardon four and commute the death sentences of the remaining 167 individuals under sentence of death-164 to life imprisonment without parole, and three to 40 years imprisonment - as "a matter of conscience" ( $p$ 212). He based the decision in part on his religious values, and also on his belief that the state's death-penalty system "did not serve justice but violated justice" ( $p$ 212). He announced that he was taking this action on January 11, 2003, in a speech delivered at Northwestern University Law School. His remarks, substantially reprinted in Until I Could Be Sure (pp 218-232), are punctuated by his ringing declaration: "I must act. Our capital system is haunted by the demon of error, error in determining guilt, and error in determining who among the guilty deserves to die" ( $\mathrm{p}$ 231). A scant 48 hours later, George Ryan's term as Governor of Illinois came to an end.

The principal strength of Until I Could Be Sure is its intimate portrait of how Ryan's private thoughts about the death penalty evolved over time, sometimes agonizingly, shaping his sense of public responsibility and leading him to halt executions in 2000 and spare the lives of all persons on Illinois' death row as he exited office in 2003. His actions dramatically energized death-penalty abolitionists and significantly altered the landscape of capital punishment nationwide. Ryan's conviction that his decisions were both necessary and justified, and his sense of satisfaction in contributing to the death penalty's demise, ring clearly throughout the volume's pages.

Ryan's reminiscences overlook, or only briefly address, other issues that warrant greater attention. One glaring oversight in light of the importance Ryan attributes to Anthony Porter's narrow escape from execution and later exoneration in arriving at his conclusion that Illinois' death penalty system was broken, is his failure to discuss the controversy surrounding the aftermath of Porter's release from death row. Alstory Simon's confession that he committed the killings for which Porter was sentenced to death led to Porter's exoneration and Simon's pleading guilty to the crimes and being sentenced to 37 years prison. As previously noted, Simon's confession was secured by a private investigator assisting Northwestern University journalism students as they sought information to upset Porter's conviction. An investigation by the Cook County prosecutor's Conviction Integrity Unit led the State's Attorney to conclude that Simon's confession was induced by improper tactics and was unreliable. Simon's convictions were vacated on the prosecution's motion, and he was released from prison in 2014 after serving 15 years of his sentence. Simon subsequently filed a $\$ 40$ million civil suit against Northwestern journalism professor David Protess and Paul Ciolino, the investigator who obtained his confession. The case eventually was settled for an undisclosed amount. In the meantime, Ciolino filed a counterclaim for defamation against Simon and his attorneys, a suit which currently remains pending. ${ }^{1}$ Ryan's

\footnotetext{
${ }^{1}$ See Ciolino v Simon, 2021 IL 126024; Sam Charles, "Defamation Suit Stemming from Alstory Simon, Anthony Porter Case Should Proceed: Appeals Court”, Chicago Sun Times (16 January 2020), online:
} 
failure to comment on these developments, which bear directly on the foundation of Anthony Porter's exoneration, is mystifying. Their significance is such that the Chicago Tribune described them as "[r]ewriting a key chapter in Illinois' death penalty history," and "forever alter[ing] the narrative arc of Illinois' history with capital punishment." 2

Another issue deserving additional attention concerns Ryan's views about life imprisonment without parole (LWOP), and the implications for all prisoners, and not just those sentenced to death, of his understanding that Illinois' justice system was badly misfiring. While announcing his blanket commutation decision, Ryan touted LWOP as an alternative to capital punishment. He mentioned a letter he received from a death row prisoner "who told me he didn't want me to do him any favors because he didn't want to face a prospect of a life in prison without parole" (p223). He envisioned a grim future confronting those whose sentences he was commuting:

They will be confined in a cell that is about five-feet-by-twelve feet, usually doublebunked. [para] Our prisons have no air-conditioning, except at our supermax facility where inmates are kept in their cell twenty-three hours a day. In summer months, temperatures in these prisons exceed one hundred degrees. It is a stark and dreary existence. They can think about their crimes. Life without parole has even, at times, been described by prosecutors as a fate worse than death. (p 223)

Characterizing LWOP as a punishment that is draconian in its own right and in some respects as harsh or even harsher than execution is a rhetorical device often employed by deathpenalty abolitionists. Yet, if problems, including the conviction of innocent persons, plagued Illinois capital cases, there is every reason to believe that miscarriages of justice were prevalent in LWOP and other considerably more routine criminal prosecutions as well. Indeed, the Commission that Ryan convened to study Illinois' death penalty system observed:

As the Commission discussed many of its proposals for capital cases, it became apparent that some issues also applied with equal force to non-capital cases. . .The Commission strongly urges consideration of ways to broaden the application of many of the

<https://chicago.suntimes.com/crime/2020/1/16/21069277/defamation-suit-alstory-simon-anthony-portercase-should-proceed-appeals-court>; Michael K McIntyre, "Alstory Simon, Freed from Prison after Wrongful Conviction, Spends His Time in Greater Cleveland Working to Free Others", Cleveland Plain Dealer (28 April 2017, updated 11 January 2019), online:

<https://www.cleveland.com/tipoff/2017/04/alstory simon freed from priso.html>; Aamer Madhani, "Northwestern University Settles Suit with Man Imprisoned After Journalism School Probe", USA Today (1 June 2018),online: <https://www.usatoday.com/story/news/2018/06/01/northwestern-wrongfulconviction-alstory-simon-david-protess/664090002/>; Steve Mills, Steve Schmadeke \& Dan Hinkel, "Prosecutors Free Inmate in Pivotal Illinois Death Penalty Case", Chicago Tribune (30 October 2014), online: <https://www.chicagotribune.com/news/ct-anthony-porter-murder-investigation-met-1031-220141030-story.html> [Mills].

${ }^{2}$ Mills, supra at note 1. 
recommendations made by the Commission to improve the criminal justice system as a whole. ${ }^{3}$

Ryan's nearly exclusive focus on errors in the administration of the death penalty unfortunately neglects what measures can and should be implemented to prevent and correct injustices, including the conviction of innocents, in the non-capital cases that make up the overwhelming business of the criminal courts.

Before Ryan was elected Governor, he served as Illinois' Secretary of State. In the epilogue to Until I Could Be Sure, Ryan acknowledges that he was under investigation during his gubernatorial administration for corruption during his tenure as Secretary of State, and that he was convicted after he left the governor's office ${ }^{4}$ and served six and one-half years in federal prison. Ryan concedes that "some people in Illinois saw my opposition to the death penalty as my attempt to divert attention away from my legal troubles" ( $\mathrm{p} 241)$. He obliquely refutes such insinuations by observing that "there were even more people who realized that my work to clean up the death penalty system and the federal investigation were two completely separate things" (id). In his foreword to the book, author and attorney Scott Turow, who served on the Illinois Death Penalty Moratorium Commission, offers a related assurance: "I have never comprehended the arguments of people who think George Ryan's response to the problems of capital punishment was driven by ulterior motives" ( $p$ xiii). While Ryan's own legal troubles and his conduct leading up to and culminating in his commutation decision could very well be utterly unrelated, it is unusual for the 237 pages sandwiched between the foreword and the epilogue to ignore the issue, and for Ryan to dismiss it without more vigor and elaboration than he did.

Until I Can Be Sure is a book without plot twists or a surprise ending. Governor Ryan's imposition of a moratorium on executions and his issuing a blanket commutation to 167 individuals on Illinois' death row and pardoning four others are among the most well-known, and in some camps, most celebrated actions taken in the modern history of capital punishment. Ryan's reports about what concerned him regarding the death penalty's administration, particularly the unimaginable horror of executing an innocent person, and how he struggled with and finally arrived at his decision to clear the state's death row, evolve in linear fashion and offer insights into the makings of these momentous personal and political decisions. While additional issues could have been addressed more fully as Ryan chronicled his thinking, the book is a worthwhile read as a first-person account of the path that led the former governor to take his truly consequential actions to focus attention on wrongful convictions and halt future executions in Illinois.

\footnotetext{
${ }^{3}$ George H Ryan, State of Illinois, Report of the Governor's Commission on Capital Punishment (April 2002) at Chapter 14 and Recommendation 83, online: 〈http://jthomasniu.org/class/Stuff/PDF/creport.pdf > . ${ }^{4}$ See United States $v$ Warner, (2007) 498 F 3d 666, rehearing en banc denied, (2007) 506 F 3d 517 (7 ${ }^{\text {th }}$ Cir), cert denied, (2008) 553 US 1064.
} 